\title{
Synthesis of new hybrid sorbent by grafting 2,6-diacetyl pyridine onto microporous $\beta$-zeolite and its application in solid phase extraction of heavy metals from environmental samples
}

\author{
HARINATH YAPATI, SREENU BHOGINENI, SURESH CHIRUMAMILLA and K SESHAIAH* \\ Inorganic and Analytical Chemistry Division, Sri Venkateswara University, Tirupati 517 502, \\ Andhra Pradesh, India \\ e-mail: seshaiahsvu@gmail.com
}

MS received 4 December 2015; revised 22 February 2016; accepted 2 March 2016

\begin{abstract}
The aim of this study was synthesis of a new hybrid material and its application in solid phase extraction of metal ions from environmental samples. The hybrid material was synthesized by grafting 3 -aminopropyl trimethoxy silane onto $\beta$-zeolite and functionalizing with 2,6-diacetyl pyridine in a stepwise covalent process. This hybrid material was characterized by FT-IR and XRD studies. The hybrid material was used as sorbent in solid phase extraction of $\mathrm{Pb}(\mathrm{II}), \mathrm{Ni}(\mathrm{II}), \mathrm{Cu}(\mathrm{II})$ and $\mathrm{Cd}(\mathrm{II})$. The method is based on the collection of metal ions onto 2,6-DAP-PA- $\beta$-zeolite and the sorbed metal ions were eluted with $10 \mathrm{~mL}$ of $1 \mathrm{M} \mathrm{HNO}_{3}$. The influences of analytical parameters such as $\mathrm{pH}$ of the sample solution, volume of sample, type and volume of eluent, flow rate of the sample and eluent that govern the efficiency and throughput of the method were evaluated. The influence effects of matrix ions (common ions other than the analyte that are present in the sample) on the retentions of the metal ions were also examined. The maximum adsorption capacity values for the metal ions onto 2,6-DAP-PA- $\beta$-zeolite, as calculated from the Langmuir model, were 112.7, 94.2, 105, and $102.8 \mathrm{mg} \mathrm{g}^{-1}$, respectively. The relative standard deviation under optimum conditions was lower than $3.10 \%$. The limits of detection were 0.035 for $\mathrm{Pb}(\mathrm{II}), 0.076$ for $\mathrm{Ni}$ (II), 0.083 for $\mathrm{Cu}$ (II) and $0.059 \mathrm{mg} \mathrm{L}^{-1}$ for $\mathrm{Cd}$ (II), respectively. The accuracy of the method was estimated by analyzing reference standard materials. The results indicate that the method is efficient for the solid phase extraction of trace levels of $\mathrm{Pb}(\mathrm{II}), \mathrm{Ni}(\mathrm{II}), \mathrm{Cu}$ (II) and Cd(II) from environmental samples.
\end{abstract}

Keywords. 2,6-DAP-PA- $\beta$-zeolite; heavy metal ions; solid phase extraction; isotherms; kinetics.

\section{Introduction}

As the number of ecological and health problems associated with environmental contamination continue to rise, the extraction and determination of trace metal ions or species from different environmental and biological matrices have become paramount importance. ${ }^{1}$ Rapid industrialization has led to increased disposal of heavy metals into the environment, causing serious soil and water pollution. ${ }^{2}$ Meanwhile, heavy metals are not biodegradable and tend to accumulate in living organisms causing various diseases and disorders. ${ }^{3,4}$ This causes severe limit of the beneficial use of heavy metal containing water for domestic or industrial applications. Therefore, monitoring of levels of cadmium (for example) in environmental and biological samples is necessary in order to assess the extent of environmental pollution and also to take the precautionary measures to control the pollution. Thus considerable attention has been paid to develop various methods for monitoring of

\footnotetext{
*For correspondence
}

metal ions from environmental and biological samples over the past decades. ${ }^{5-7}$ Solid phase extraction (SPE) is one of the most important methods for separation and extraction of trace elements in samples. ${ }^{8-12}$

It should be noted that the sorbent material plays a fundamentally crucial role in solid phase extraction. Thus, the development of new sorbent material with high selectivity, stability and extraction efficiency for solid phase extraction is of interest to analysts. In recent years, much attention has been paid to the chemical modification of the surface of silica with various functional groups to improve its physical and chemical properties. In the solid phase extraction, various sorbents such as thiol cotton, ${ }^{13}$ activated carbon, ${ }^{14}$ adsorption resins, ${ }^{15}$ cellulose, ${ }^{16}$ polythioether ${ }^{17}$ microcrystalline naphthalene, ${ }^{18,19}$ Amberlite XAD-2 resin, ${ }^{20}$ octadecyl silica membrane disk ${ }^{21}$ and synthetic zeolites ${ }^{22}$ have been used.

Among these materials, nanoporous zeolites functionalized with various organic materials is increasingly utilized as an adsorbent because of its high selectivity and chemical stability for heavy metal ions 
adsorption. ${ }^{23-25}$ Zeolites are a type of porous materials having crystalline alumino silicate materials, consisting of either $\mathrm{Si}$ or $\mathrm{Al}$ atoms interconnected via oxygen bridges. $\mathrm{Si}$ and $\mathrm{Al}$ are also referred as "T- atoms", as they are the center of tetrahedral $\mathrm{SiO}_{4}$ or $\mathrm{AlO}_{4}$ structures. These tetrahedral structures are the building blocks forming the several crystalline lattice structures known so far, from either naturally occurring or specifically designed synthetic zeolites. Their intricate structural arrangement is also responsible for the high specific surface area of these materials. This is a key factor for the excellent adsorption properties of these materials. ${ }^{26}$ The adsorption capacity and selectivity of these sorbents mainly depend on the surface modification of material by organic functionalization consisting of oxygen, nitrogen and sulfur atoms that can act as coordination sites for the metal ions. ${ }^{27}$

The objective of this research is synthesis of a new hybrid material by grafting of 3-aminopropyl trimethoxy silane onto $\beta$-zeolite and functionalization with 2,6-diacetyl pyridine in a stepwise covalent process. This hybrid material was characterized by FTIR and XRD studies. The hybrid material was used as sorbent in solid phase extraction of $\mathrm{Pb}$ (II), $\mathrm{Ni}$ (II), $\mathrm{Cu}(\mathrm{II})$ and $\mathrm{Cd}(\mathrm{II})$. The main advantage of the new sorbent developed was the presence of chelating sites containing $\mathrm{N}$ and $\mathrm{O}$ on the surface of sorbent material which coordinate to the metal ions and pre-concentrate the metal ions. The maximal adsorption capacities of the metal ions onto the 2,6-DAP-PA- $\beta$-zeolite, as calculated from the Langmuir model, were 112.7, 94.2, 105 , and $102.8 \mathrm{mg} \mathrm{g}^{-1}$, respectively. The relative standard deviation under optimum conditions is lower than $3.10 \%$. The limits of detection in were 0.035 for $\mathrm{Pb}(\mathrm{II})$, 0.076 for $\mathrm{Ni}$ (II), 0.083 for $\mathrm{Cu}$ (II) and $0.059 \mathrm{mg} \mathrm{L}^{-1}$ for $\mathrm{Cd}(\mathrm{II})$ respectively.

\section{Experimental}

\subsection{Apparatus}

Atomic absorption spectrometer (SHIMADZU AA6300, Japan) equipped with single element hallow cathode lamps and an air-acetylene burner was used for the determination of the metals. $\mathrm{pH}$ values were controlled with a Elico LI120 pH meter. FT-IR spectra (4000-500 $\mathrm{cm}^{-1}$ ) were recorded using (Bruker-Alpha, Germany) FT-IR spectrometer. Powder X-ray diffractograms (XRD) of the materials were recorded using a PANalytical X'pert Pro dual goniometer diffractometer. $\mathrm{N}_{2}$ adsorption-desorption isotherms and pore size distributions were determined using a Micrometrics ASAP 2020 instrument and Autosorb 1C
Quanta chrome (USA). Carbon, Nitrogen, Oxygen and Hydrogen were estimated using a Carlo-Erba CHN analyzer (EA1108 Elemental Analyzer).

\subsection{Standard solutions and reagents}

The stock standard solutions $\left(1.000 \mathrm{~g} \mathrm{~L}^{-1}\right)$ of $\mathrm{Pb}(\mathrm{II})$, $\mathrm{Ni}(\mathrm{II}), \mathrm{Cu}$ (II) and $\mathrm{Cd}(\mathrm{II})$ were prepared by dissolving appropriate amounts of $\mathrm{Pb}\left(\mathrm{NO}_{3}\right)_{2}, \mathrm{NiCl}_{2} \cdot 6 \mathrm{H}_{2} \mathrm{O}$, $\mathrm{CuCl}_{2} \cdot 6 \mathrm{H}_{2} \mathrm{O}, \mathrm{CdCl}_{2} \cdot \mathrm{H}_{2} \mathrm{O}$ (purchased from Merck) in high purity Milli Q water, respectively. Working solutions were prepared by appropriate dilutions of their stock solutions. All reagents used were of analytical grade. High purity Milli Q water obtained from a Millipore system (Merck Millipore, India) was used throughout this work. All containers were treated with $10 \%$ (v/v) $\mathrm{HNO}_{3}$ for at least $24 \mathrm{~h}$, rinsed with high purity Milli Q water and dried at room temperature before usage.

\subsection{Preparation of micro porous $\beta$-zeolite and grafting of 3-aminopropyl trimethoxy silane onto $\beta$-zeolite}

$\mathrm{NaOH}, \mathrm{KOH}$ and tetraethyl ammonium hydroxide (TEAOH) were taken in a polypropylene beaker to which fumed silica and water were added and the gel was stirred for $1 \mathrm{~h}$. To this ammonium sulphate in deionized water was added over a period of half an hour with stirring for one more hour and deionized water was added. The gel obtained ( $\mathrm{pH} 12.5)$ was transferred into a stainless steel autoclave and subjected to hydrothermal treatment at $413 \mathrm{~K}$. Crystallized zeolite was obtained in 7 days. The zeolite was then separated from the mother liquor and washed with deionized water, dried at $383 \mathrm{~K}$ for $12 \mathrm{~h}$ and calcined at $783 \mathrm{~K}$ for $16 \mathrm{~h}$.

\subsection{Preparation of hybrid material: 2,6-DAP-PA- $\beta$-zeolite}

$1.0 \mathrm{~g}$ of zeolite was dissolved in $50 \mathrm{~mL}$ of toluene and $0.6 \mathrm{~g}$ 3-aminopropyl trimethoxysilane (PA) was added to it under $\mathrm{N}_{2}$ atmosphere condition, the reaction mixture was stirred at $110^{\circ} \mathrm{C}$ for $2 \mathrm{~h}$ (scheme 1). The resulted mixture was filtered and washed with dichloromethane (DCM) and the obtained product was dried in oven at $60^{\circ} \mathrm{C}$ for $6 \mathrm{~h}$. The final compound was subjected soxhlet extraction to remove the unreacted compounds.

As-obtained product was further functionalized with 2,6-diacetyl pyridine (2,6-DAP). For this purpose, the obtained product was first dissolved in $20 \mathrm{~mL}$ of toluene and to it $50 \mathrm{mg}$ of 2,6-diacetyl pyridine (2,6-DAP) was added and refluxed for $2 \mathrm{~h}$. The final synthesized 


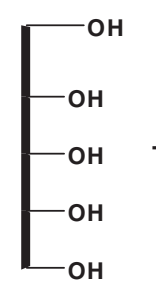

$\beta$-Zeolite

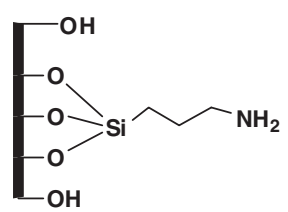

3-aminopropyl trimothoxy silane graf ted $\beta$-Zeolite

Scheme 1. Grafting of 3-aminopropyl trimethoxy silane onto zeolite.

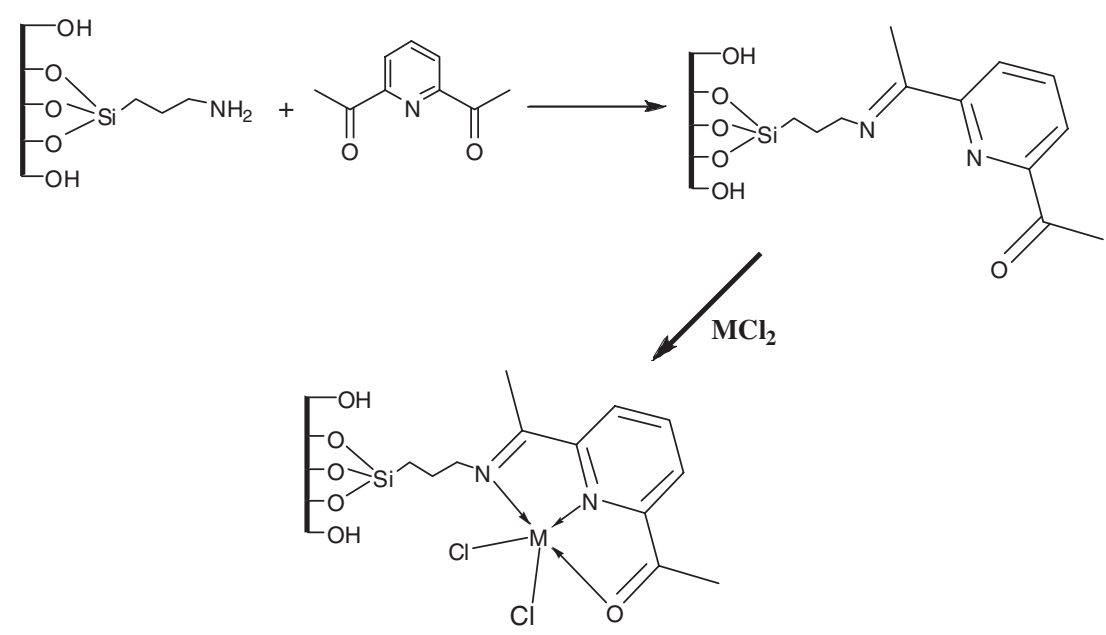

Scheme 2. Preparation of hybrid material: 2,6-DAP-PA- $\beta$-zeolite and binding of metal ions.

compound, 2,6-DAP-PA- $\beta$-zeolite was obtained after removal of solvent through filtration and drying in hot air oven at $60^{\circ} \mathrm{C}$ for $12 \mathrm{~h}$. The scheme 2 shows the mechanism of grafting of 2,6-DAP-PA onto $\beta$-zeolite.

\subsection{Preparation of column}

$50 \mathrm{mg}$ of 2,6 -DAP-PA- $\beta$-zeolite was packed in glass column (i.d. $1.0 \mathrm{~cm}$, length of $10 \mathrm{~cm}$ ) plugged with a small portion of glass wool at both ends. Before use, methanol and Milli Q water were passed through the column in sequence in order to clean it. Then the column was conditioned to $\mathrm{pH} 5.5$ with $0.1 \mathrm{M}$ $\mathrm{NH}_{4} \mathrm{Cl} / \mathrm{NH}_{3} \cdot \mathrm{H}_{2} \mathrm{O}$ buffer solution.

\subsection{Solid phase extraction procedure}

The $\mathrm{pH}$ of the solution was adjusted to 5 for $\mathrm{Pb}$ (II) and 6 for $\mathrm{Ni}(\mathrm{II}), \mathrm{Cu}(\mathrm{II})$ and $\mathrm{Cd}(\mathrm{II})$ with $\mathrm{HCl}$ and $\mathrm{NH}_{3} \cdot \mathrm{H}_{2} \mathrm{O}$ and passed through the 2,6-DAP-PA- $\beta$-zeolite loaded column at a flow rate of $2 \mathrm{~mL} \mathrm{~min}^{-1}$ with aid of suction pump. The analytes were then eluted with $10 \mathrm{~mL}$ of $1 \mathrm{M}$ $\mathrm{HNO}_{3}$. The metal ion concentration of the eluent was measured by flame AAS.

\subsection{Vegetable samples preparation}

Sample preparation of the vegetables was carried out by microwave digestion. Approximately $1 \mathrm{~g}$ (dry mass) of vegetable materials was weighed directly into the PTFE vessels, to which $10 \mathrm{~mL}$ of concentrated $\mathrm{HNO}_{3}$ was added and the vessels were capped immediately. The digestion programme consisted of a ramp time of $10 \mathrm{~min}$ to reach $150^{\circ} \mathrm{C}$ and a dwell time of $10 \mathrm{~min}$ at $150^{\circ} \mathrm{C}$. The power was $800 \mathrm{~W}$. After the completion of program, vessels were cooled, vented and opened and then $2 \mathrm{~mL}$ of $30 \% \mathrm{H}_{2} \mathrm{O}_{2}$ was added and filtered the solutions into $25 \mathrm{~mL}$ volumetric flasks and made up with double distilled water. Blanks were prepared by following similar digestion procedure without vegetable.

\subsection{Water sample preparation}

The water samples were collected in cleaned polyethylene bottles and filtered through a cellulose membrane filter of pore size $0.45 \mu \mathrm{m}$ and the $\mathrm{pH}$ of the sample $(500 \mathrm{~mL})$ was adjusted to $5.5 \pm 0.1$ with $0.01 \mathrm{M}$ $\mathrm{HCl}$ and $\mathrm{NH}_{3} \cdot \mathrm{H}_{2} \mathrm{O}$ and $2 \mathrm{~mL}$ of acetate buffer solution. The solution was passed through the column containing $50 \mathrm{mg}$ of 2,6 -DAP-PA- $\beta$-zeolite. The sample was passed through the column at the flow rate of 
$2.0 \mathrm{~mL} \mathrm{~min}^{-1}$ and then washed with $10 \mathrm{~mL}$ on doubly distilled water. The adsorbed metal ions were eluted with $10 \mathrm{~mL}$ of $1 \mathrm{M} \mathrm{HNO}_{3}$ and determined as described in recommended solid phase extraction procedure.

\section{Results and Discussion}

\subsection{FT-IR analysis}

Samples of $\beta$-zeolite, PA- $\beta$-zeolite and 2,6-DAP-PA$\beta$-zeolite (before and after metal binding) were analyzed by FT-IR; spectra are shown in figure S1 (see Supplementary Information). The wide bands at 1240$1030 \mathrm{~cm}^{-1}$ are typically regarded as $\mathrm{Si}-\mathrm{O}-\mathrm{Si}$ bands of the condensed silica network. The peak at $1630 \mathrm{~cm}^{-1}$ is attributed to the bending vibration of adsorbed water and the peak at $806 \mathrm{~cm}^{-1}$ can be assigned to the symmetric stretching vibration of $\mathrm{Si}-\mathrm{O}$. These three features are present in all samples analyzed. When comparing $\beta$-zeolite (spectrum i) with PA- $\beta$-zeolite (spectrum ii), the peak at $1470 \mathrm{~cm}^{-1}$ indicates successful incorporation of the amine functionality as this peak (assigned to $\mathrm{N}-\mathrm{H}$ stretch) which is not present in the $\beta$ zeolite spectrum. There is also a weak band at $693 \mathrm{~cm}^{-1}$ in the spectrum of PA- $\beta$-zeolite corresponding to $\mathrm{N}-\mathrm{H}$ bending vibration providing further evidence of incorporation of the amine functional group onto the silica surface. The peak at $1640 \mathrm{~cm}^{-1}$ is attributed to the stretching vibration of $\mathrm{C}=\mathrm{N}$ indicating the functionalization of amine with 2,6-Diacetyl pyridine (spectrum iii). Differences were also observed between the spectra obtained for 2,6-DAP-PA- $\beta$-zeolite before loading with metal ions (spectrum iv). Specifically, the $C=N$ stretch at $1640 \mathrm{~cm}^{-1}$ shifted towards higher frequency after metal loading. The $\mathrm{Si}-\mathrm{OH}$ stretch at $970 \mathrm{~cm}^{-1}$ was also shifted to $950 \mathrm{~cm}^{-1}$, illustrating the influence of the associated anion with the chelation. A sharp peak at $823 \mathrm{~cm}^{-1}$ also appeared in all 2,6-DAP-PA- $\beta$-zeolite samples after loading with metal ions.

Based on these observations it can be summarized that the external functional groups like $\mathrm{C}=\mathrm{N}, \mathrm{C}=\mathrm{O}$ are involved in chelation with metal ions as shown in scheme 2. The broad band at $1340-1400 \mathrm{~cm}^{-1}$ corresponds to $\mathrm{M}-\mathrm{N}$ stretch and the sharp peak at $823 \mathrm{~cm}^{-1}$ corresponds to $\mathrm{M}-\mathrm{O}$ vibration is the evidence of metal loading. Thus, the FT-IR spectra establish the successful grafting of organic moiety on the surface of $\beta$-zeolite and metal chelation with organic functional groups.

\subsection{XRD analysis}

The X-ray patterns of the zeolite remained unchanged after the reaction except that the relative intensities of the peaks decreased as shown in figure 1. This lowering of peak intensities might be due to X-ray shielding caused by absorption of carbonaceous material during reaction by the zeolite samples. A similar observation has been reported by Breck et al., ${ }^{28}$ on hydration of zeolites and Long et al., ${ }^{29}$ for the methylation of naphthalene by methane over substituted aluminophosphate molecular sieves. The fact that the X-ray patterns of the $\beta$-zeolite samples remained unchanged after reaction with 2,6-DAP-PA, except for the intensity change, indicates that their crystalline structure remained intact after the reaction.

\subsection{N2-Adsorption/Desorption isotherms and Elemental analysis}

The nitrogen adsorption-desorption isotherms of $\beta$-zeolite and 2,6-DAP-PA modified $\beta$-zeolite (figures $2 \mathrm{a}$ and $2 b)$ show characteristic type I isotherms indicating the microporous structures which were not disturbed even

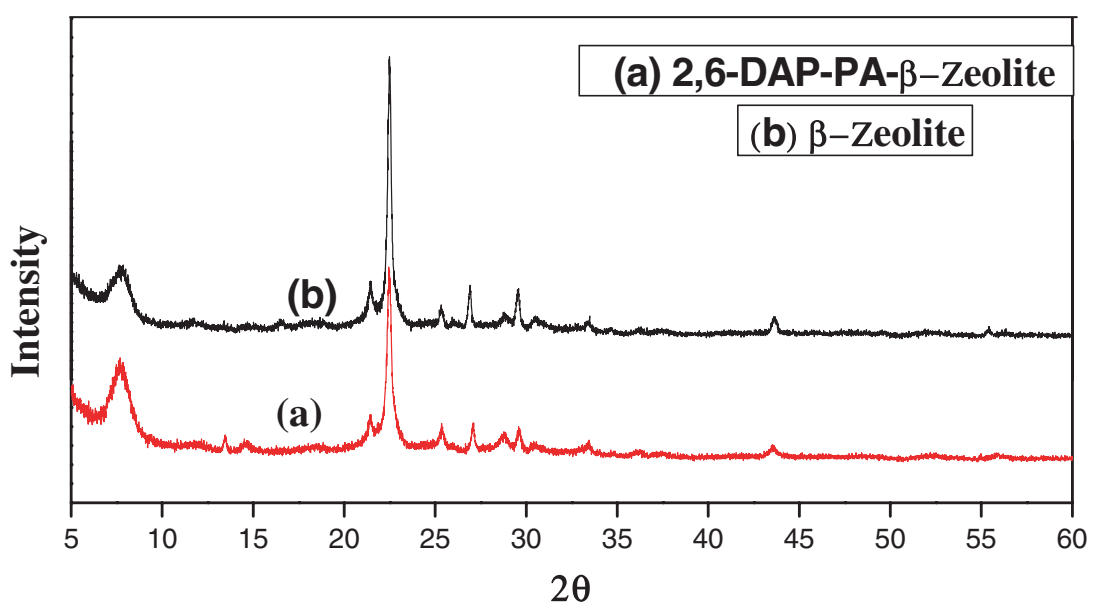

Figure 1. XRD patterns of prepared (a) 2,6-DAP-PA- $\beta$-zeolite and (b) $\beta$-zeolite. $2 \theta$ values are in degrees. 

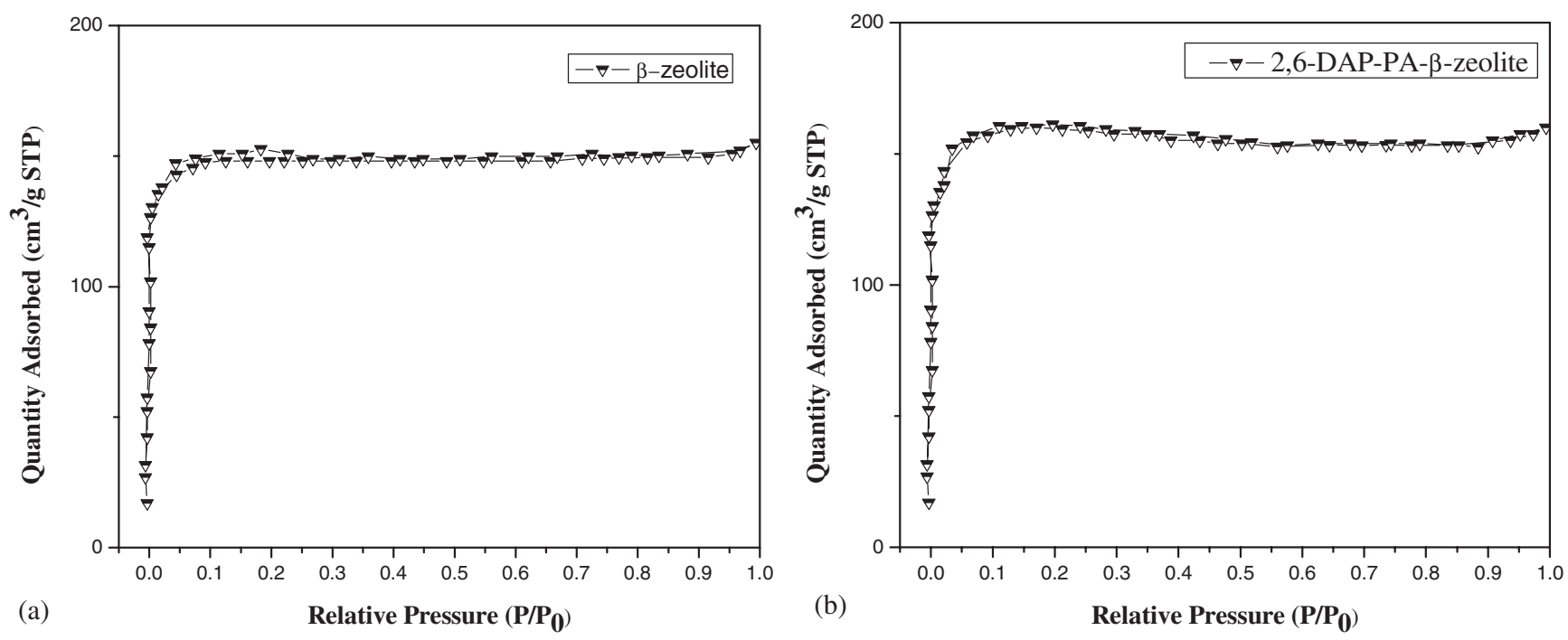

Figure 2. $\mathrm{N}_{2}$ adsorption-desorption isotherm of (a) $\beta$-zeolite and (b) 2,6-DAP-PA- $\beta$-zeolite.

after surface modification. The surface area and the pore size were calculated by BET and BJH methods and results are summarized in table S1 in SI. The surface area, pore size and pore volume of $\beta$-zeolite were decreased on surface modification.

Elemental analysis data of the 2,6-DAP-PA- $\beta$-zeolite (table S2) indicates that the carbon and hydrogen contents increased upon surface modification indicating the anchoring of organic functional groups onto $\beta$-zeolite.

\subsection{Effect of $p H$}

The $\mathrm{pH}$ of the aqueous solution is an important operational parameter in the solid phase extraction process because it affects the solubility of the metal ions, concentration of the counter ions on the functional groups of the adsorbent and the degree of ionization of the adsorbate during reaction. ${ }^{30,31}$ At $\mathrm{pH}$ value higher than 6.0 , most of the heavy metal ions tend to form precipitation as hydroxides. And the "true" adsorption capacity of 2,6-DAP-PA- $\beta$-zeolite could be masked by precipitation. ${ }^{32}$ Thus, the adsorption of heavy metal onto 2,6-DAP-PA- $\beta$-zeolite at $\mathrm{pH}$ value ranging from 2.0 to 9.0 was studied, as shown in figure 3 . From figure 3 , an increase in $\mathrm{pH}$ increases adsorption, reaching the maximum capacity at a $\mathrm{pH} 5$ for $\mathrm{Pb}(\mathrm{II})$ and pH 6 for $\mathrm{Ni}(\mathrm{II}), \mathrm{Cu}$ (II) and $\mathrm{Cd}(\mathrm{II})$. The results of the $\mathrm{pH}$ on the recoveries of the elements are shown in figure 3 . The lower adsorption of heavy metal at acidic $\mathrm{pH}$ is probably due to the following reasons. At lower $\mathrm{pH}$ values, where the concentration of $\mathrm{H}^{+}$is high, the competition by the negative sites on the zeolite surface is enhanced and the metal sorption is reduced

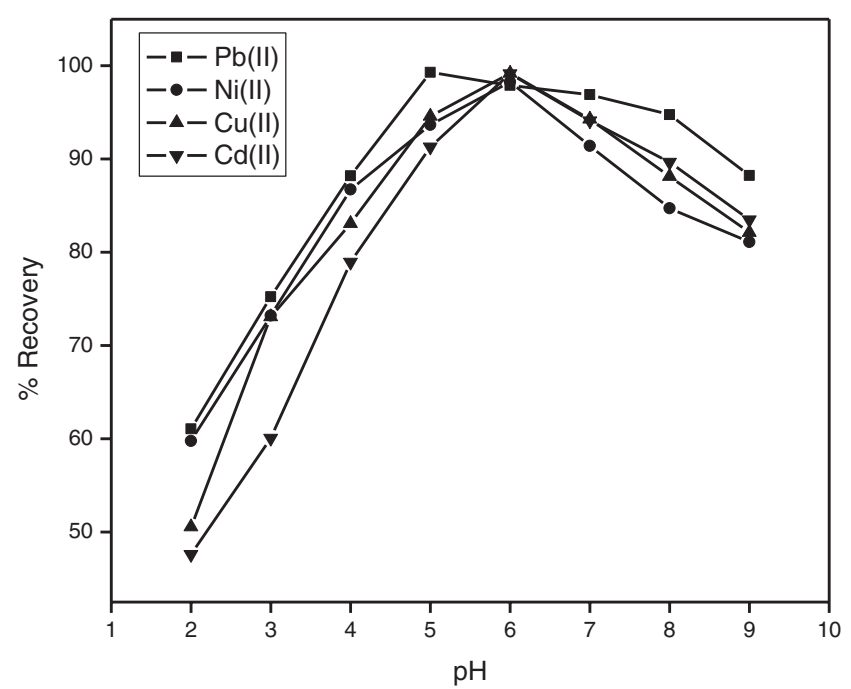

Figure 3. Effect of $\mathrm{pH}$ on recovery of metal ions

accordingly. ${ }^{33,34}$ In addition, zeolite begins to collapse or dissolve with decreasing $\mathrm{pH}$, particularly when the $\mathrm{pH}$ is below 4.0. ${ }^{35}$ Hence, $\mathrm{pH} 5$ for $\mathrm{Pb}(\mathrm{II})$ and $\mathrm{pH} 6$ for $\mathrm{Ni}(\mathrm{II}), \mathrm{Cu}(\mathrm{II})$ and $\mathrm{Cd}(\mathrm{II})$ was selected as the optimum $\mathrm{pH}$ for all subsequent studies.

\subsection{Optimization of elution conditions}

3.5a Selection of eluent: According to the chemical structure of modified zeolite, acidic solution is needed for desorption of ions from column, thus $\mathrm{HCl}, \mathrm{HNO}_{3}$ and $\mathrm{H}_{2} \mathrm{SO}_{4}$ were used for this purpose. $10 \mathrm{~mL}$ of solution containing $1.0 \mathrm{mg} \mathrm{L}^{-1}$ of $\mathrm{Pb}(\mathrm{II}), \mathrm{Ni}(\mathrm{II}), \mathrm{Cu}$ (II) and $\mathrm{Cd}(\mathrm{II})$ at appropriate $\mathrm{pHs}$ was passed through the column and eluted with $10 \mathrm{~mL}$ of $1 \mathrm{M}$ acids, separately. The recovery of elements for $\mathrm{HCl}$ was a little better 
than $\mathrm{HNO}_{3}$ and $\mathrm{H}_{2} \mathrm{SO}_{4}$ was not good. Although, the recovery of elements for $\mathrm{HCl}$ was better than $\mathrm{HNO}_{3}$, we used $\mathrm{HNO}_{3}$ as eluent due to avoid the risk of chloride interference. Thus, $\mathrm{HNO}_{3}$ was selected for further experiments.

3.5b Effect of sample flow rate: The sample flow rate should be optimized to ensure quantitative adsorption of the target species. The influences of the sample flow rate on the adsorption percentage of $1.0 \mathrm{mg} \mathrm{L}^{-1} \mathrm{~Pb}$ (II) $(\mathrm{pH}$ 5.5), $\mathrm{Ni}(\mathrm{II}), \mathrm{Cu}(\mathrm{II})$ and $\mathrm{Cd}(\mathrm{II})(\mathrm{pH} 6.0)$ were studied and the results demonstrated that quantitative recoveries could be obtained for both species when the sample flow rate was varied from 0.5 to $5 \mathrm{~mL} \mathrm{~min}{ }^{-1}$, indicating a rapid reaction mechanism between metal ions and 2,6DAP-PA- $\beta$-zeolite at appropriate $\mathrm{pH}$ values. In subsequent experiments, a sample flow rate of $2.0 \mathrm{~mL} \mathrm{~min}^{-1}$ was used.

3.5c Eluent volume: The volume of eluent influences pre-concentration factor. The volume of the eluent must be as low as possible to achieve the highest enrichment factor. For this purpose $10 \mathrm{~mL}$ of solution containing $1.0 \mathrm{mg} \mathrm{L}^{-1}$ of $\mathrm{Pb}$ (II) (pH 5.5) and $\mathrm{Ni}(\mathrm{II})$, $\mathrm{Cu}$ (II), $\mathrm{Cd}$ (II) ( $\mathrm{pH}$ 6.0) were passed through the column and eluted with 5-20 mL $1.0 \mathrm{M} \mathrm{HNO}_{3}$ separately. The results indicated that quantitative recoveries of $1.0 \mathrm{mg} \mathrm{L}^{-1}$ of $\mathrm{Pb}$ (II), $\mathrm{Ni}$ (II), $\mathrm{Cu}$ (II) and $\mathrm{Cd}(\mathrm{II})$ were obtained with the first $10 \mathrm{~mL}$ of eluent. Therefore, $10 \mathrm{~mL}$ of $1 \mathrm{MHNO}_{3}$ was used as eluent in the subsequent experiments.

\subsection{Sorption capacity and detection limits}

The adsorption capacity of 2,6-DAP-PA- $\beta$-zeolite for various metal ions were determined by batch method. The resin $(50 \mathrm{mg})$ was saturated with metal ion solution (concentration $25 \mu \mathrm{g} \mathrm{L}^{-1}$ ) by equilibrating on a mechanical shaker under optimum conditions. The solid matrix was filtered and removed. The concentration of these metal ions in the solution was determined by FAAS. The amount of metal ions adsorbed onto 2,6DAP-PA- $\beta$-zeolite were obtained by mass balance. The sorption capacity values of resin were $112.76 \mathrm{mg} \mathrm{g}^{-1}$ for $\mathrm{Pb}(\mathrm{II}), 94.25 \mathrm{mg} \mathrm{g}^{-1}$ for $\mathrm{NI}(\mathrm{II}), 105.07 \mathrm{mg} \mathrm{g}^{-1}$ for $\mathrm{Cu}(\mathrm{II})$ and $102.80 \mathrm{mg} \mathrm{g}^{-1}$ for $\mathrm{Cd}(\mathrm{II})$. The detection limit is defined as the concentration of metal ion which gives a signal equivalent to mean of the reagent blank prepared plus three times the standard deviation of the blank. The detection limits in $\mathrm{mg} \mathrm{L}^{-1}$ were 0.035 for $\mathrm{Pb}$ (II), 0.076 for $\mathrm{Ni}(\mathrm{II}), 0.083$ for $\mathrm{Cu}(\mathrm{II})$ and 0.059 for Cd(II), respectively.

\subsection{Adsorption isotherms}

The equilibrium adsorption isotherm studies were helpful to predict the specific relation between the equilibrium concentration of target species and the surface of the adsorbent material. Further, sorption isotherm studies are essential to design an adsorption system. A number of isotherm models are available for the determination sorption process, the well-known sorption isotherms used to correlate sorption equilibria of heavy metal sorption are: Langmuir and Freundlich isotherm models. A relatively high $\mathrm{R}^{2}$ and low $\chi^{2}$ values were used to identify the suitable isotherm for sorption of metal ions onto 2,6-DAP-PA- $\beta$-zeolite. The parameters of the isotherm models and the correlation coefficients for the isotherm plots of $\mathrm{Pb}$ (II), $\mathrm{Ni}$ (II), $\mathrm{Cu}$ (II) and $\mathrm{Cd}(\mathrm{II})$ were calculated with Origin 8.0 software by plotting $\mathrm{C}_{\mathrm{e}}$ (equilibrium concentration) versus $\mathrm{q}_{\mathrm{e}}$ (equilibrium adsorbed amount) and the results are presented in table S3. It is evident from the data that the sorption of $\mathrm{Pb}$ (II), $\mathrm{Ni}(\mathrm{II}), \mathrm{Cu}(\mathrm{II})$ and $\mathrm{Cd}(\mathrm{II})$ onto 2,6-DAPPA- $\beta$-zeolite was well fitted to the Langmuir isotherm model. The maximum saturated monolayer adsorption capacity, $\mathrm{q}_{\max }$ was found to be $112.76 \mathrm{mg} \mathrm{g}^{-1}$ for $\mathrm{Pb}(\mathrm{II})$, $94.25 \mathrm{mg} \mathrm{g}^{-1}$ for $\mathrm{NI}(\mathrm{II}), 105.07 \mathrm{mg} \mathrm{g}^{-1}$ for $\mathrm{Cu}$ (II) and $102.80 \mathrm{mg} \mathrm{g}^{-1}$ for $\mathrm{Cd}(\mathrm{II})$. The high $\mathrm{R}^{2}$ value $>0.99$ and low $\chi^{2}$ value 0.26 , indicate that the Langmuir isotherm is favorable to the adsorption of $\mathrm{Pb}$ (II), $\mathrm{Ni}$ (II), $\mathrm{Cu}$ (II) and $\mathrm{Cd}(\mathrm{II})$ confirming the monolayer adsorption of metal ions onto 2,6-DAP-PA- $\beta$-zeolite.

\subsection{Kinetics of sorption}

Sorption kinetics is one of the important parameter that is being studied in SPE methods because it provides the rate of sorption of metals onto resin loaded with a reagent in the dynamic column mode for routine analysis. The rate of uptake of metal ions onto 2,6-DAP-PA- $\beta$-zeolite was studied by batch method. One gram of functionalized resin was added to $50 \mu \mathrm{g}$ of individual metal ion solutions and stirred for 5 , $10,20,30,40,50,60,90$, and $120 \mathrm{~min}$ at a fixed temperature $\left(30 \pm 0.1^{\circ} \mathrm{C}\right)$. The metal ions adsorbed onto the resin were eluted with $1.0 \mathrm{M} \mathrm{HNO}_{3}$ and analyzed by AAS. The amount of metal adsorbed onto the resin with time is graphically presented in figure S2 in Supplementary Information. The loading half-time, $t_{1 / 2}$, needed to reach $50 \%$ sorption of the total loading capacity has been found to be less than $5 \mathrm{~min}$ for each metal ion [Pb(II), 4.0; Ni(II), 3.5; $\mathrm{Cu}(\mathrm{II}), 3.7$ and $\mathrm{Cd}(\mathrm{II}), 4.3 \mathrm{~min}$, respectively]. The kinetics of the functionalized zeolite-metal interaction was sufficiently rapid for all of the metal ions at 
optimum $\mathrm{pH}$. The faster uptake of these metal ions on 2,6-DAP-PA- $\beta$-zeolite reflects a good accessibility of the chelating sites of the resin to metal ions.

\subsection{Effect of diverse ions}

In the atomic absorption spectrometric determination of heavy metal ions, concentration of diverse ions is a vital problem. In order to assess the possible analytical applications of the recommended solid phase extraction procedure, the effect of foreign ions that interfere in the determination of trace of these ions or/and often accompany analyte ions in various real environmental samples was examined using the optimized conditions. The observed results are summarized in table S4 (in SI). Tolerance limit is defined as the highest amount of foreign ions that produced an error not exceeding $5 \%$ by the combination of the column solid phase extraction and atomic absorption spectrophotometric determination methods.

\subsection{Accuracy of the proposed method}

The accuracy of the developed SPE procedure was evaluated by measuring the metal ions in standard reference materials (NIST 1643e water) and the results are presented in table S5 (in SI). Concentrations of metal ions were determined by the proposed method are in good agreement with the certified values. The observed results indicate the applicability of developed procedure in determination of $\mathrm{Pb}$ (II) $\mathrm{Ni}$ (II), $\mathrm{Cu}$ (II) and $\mathrm{Cd}$ (II) accurately and free of interferences.

\subsection{Determination of trace metal ions in water samples}

Water samples were collected from pond and bore well (Karakambadi, Tirupati, A.P., India). The concentrations of $\mathrm{Pb}(\mathrm{II}), \mathrm{Ni}(\mathrm{II}), \mathrm{Cu}(\mathrm{II})$ and $\mathrm{Cd}(\mathrm{II})$ were determined, and the results are listed in table S6 (in SI). The results revealed that the concentration of $\mathrm{Pb}(\mathrm{II})$ is in the range of $8.42-10.31 \mu \mathrm{g} \mathrm{L}^{-1}$; $\mathrm{Ni}(\mathrm{II}): 14.32-$ $16.18 \mu \mathrm{g} \mathrm{L}^{-1}$; $\mathrm{Cu}(\mathrm{II}): 17.56-16.46 \mu \mathrm{g} \mathrm{L}^{-1}$; and $\mathrm{Cd}(\mathrm{II})$ : $10.72-11.54 \mu \mathrm{g} \mathrm{L}^{-1}$.

\subsection{Determination of trace metal ions in vegetable samples}

Vegetable samples, namely, cucumber (Cucumis sativus), chillies (Capsicum annuum), beans (Phaseolus) and bitter gourd (Momordica charantia), were collected from nearby agricultural fields of Tirupati town; the concentrations of $\mathrm{Pb}(\mathrm{II}), \mathrm{Ni}(\mathrm{II}), \mathrm{Cu}(\mathrm{II})$ and
$\mathrm{Cd}(\mathrm{II})$ were determined, and the results are presented in table S7 (in SI). The concentrations of four metal ions in vegetables were in the range of $0.018-0.026 \mathrm{mg} \mathrm{g}^{-1}$ for lead, $1.983-3.045 \mathrm{mg} \mathrm{g}^{-1}$ for nickel, 0.189 $0.598 \mathrm{mg} \mathrm{g}^{-1}$ for copper, and $0.058-0.136 \mathrm{mg} \mathrm{g}^{-1}$ for cadmium.

\section{Conclusions}

A hybrid material was successfully fabricated by grafting 2,6-diacetylpyridine onto the surface of zeolite using multistep covalent process and its application potential in solid phase extraction was examined. The synthesized hybrid material showed good adsorption capacity towards $\mathrm{Pb}(\mathrm{II}), \mathrm{Ni}(\mathrm{II}), \mathrm{Cu}$ (II) and $\mathrm{Cd}(\mathrm{II})$. Adsorption of these metals can be carried out in $\mathrm{pH} 6$ for $\mathrm{Ni}(\mathrm{II}), \mathrm{Cu}(\mathrm{II})$ and $\mathrm{Cd}(\mathrm{II})$, while selective adsorption of $\mathrm{Pb}$ (II) can be carried out in $\mathrm{pH}$ 5. The synthesized hybrid material provides fast analysis, good sensitivity and excellent detection limit. The method was successfully applied to the determination of $\mathrm{Pb}$ (II), $\mathrm{Ni}(\mathrm{II})$, $\mathrm{Cu}(\mathrm{II})$ and $\mathrm{Cd}(\mathrm{II})$ in water and vegetable samples.

\section{Supplementary Information (SI)}

Figures S1 and S2 and tables S1-S7 are available in Supplementary Information at www.ias.ac.in/chemsci.

\section{Acknowledgements}

The authors wish to thank the CSIR, Government of India (Project 02(0136)/ 13/ EMR-II) for their generous support.

\section{References}

1. Xijun C, Haixia L, Yuemei C, Xiangbing Z, Yunhui Z, Zheng H and Qun H 2008 J. Mol. Str. 89145

2. Elouear Z, Bouzid J, Boujelben N, Feki M, Jamoussi F and Montiel A 2008 J. Hazard. Mater. 156412

3. Jamil T S, Ibrahim H S, Abd El-Maksoud I H and El-Wakeel S T 2010 Desalination 25834

4. Prasad M, Xu H Y and Saxena S 2008 J. Hazard. Mater. 154221

5. Pagnanelli F, Mainelli S, Vegliò F and Toro L 2003 Chem. Eng. Sci. 584709

6. Miretzky P, Saralegui A and Cirelli A F 2006 Chemosphere $\mathbf{6 2} 247$

7. Sakai Y and Mor N 1986 Talanta 33161

8. Jackwerth E, Yang X G and Xu C 1989 Anal. Chem. 334 514

9. Elci L, Soylak M, Uzun A, Büyükpatır E and Doğan M 2000 Fres. J. Anal. Chem. 368358

10. Brainina Kh and Neyman E 1993 In Monographs on analytical chemistry and its application (New York: Wiley) 
11. Wang J 1985 In Stripping Analysis: Principles, Instrumentation and Applications (Deerfield Beach: $\mathrm{VcH}$ Publishers)

12. Yu M Q, Liu G Q and Jin Q 1983 Talanta 30265

13. Soylak M and Elci L 1997 Int. J. Environ. Anal. Chem. 6651

14. Vanderborght B M and Vangrieken R E 1977 Anal. Chem. 49311

15. Taher M A 2001 Anal. Sci. 17969

16. Burba P and Willmer P G 1983 Talanta 30381

17. Khan A S and Chow A 1986 Talanta 33182

18. Taher M A 2000 Talanta 52181

19. Taher M A and Puri B K 1999 Talanta 48355

20. Kumar B N, Ramana D K V, Harinath Y, Seshaiah K and Wang M C 2011 J. Agric. Food. Chem. 5911352

21. Bagheri M, Mashhadizadeh M H and Razee S 2003 Talanta 60839

22. Pena Y P, Lopez W, Burgurea J L, Burgurea M, Gallignani M, Brunetto R, Carrerro P, Rondon C and Ambert R 2000 Anal. Chim. Acta 403249

23. Valentin V, Gerardo M, Svetlana M and Javier P 2013 Chem. Soc. Rev. 42263
24. Chandra D, Das S K and Bhaumik A 2010 Micropor. Mesopor. Mat. 12834

25. Chandra D, Yokoi T, Tatsumi T and Bhaumik A 2007 Chem. Mater. 195347

26. Hugo F and Cristina Q 2014 J. Hazard. Mater. 274287

27. Jal P K, Patel S and Mishra B K 2004 Talanta 621005

28. Breck D W, Eversole W G, Milton R M, Reed T B and Thomas T L 1956 J. Am. Chem. Soc. 785963

29. He S J X, Long M A, Atalla M I and Wilson M A 1992 Energy Fuels 6498

30. Amuda O S, Giwa A A and Bello I A 2007 Biochem. Eng. J. 36174

31. Aklil A, Mouflih M and Sebti S 2004 J. Hazard. Mater. A 112183

32. Kocaoba S, Orhan Y and Akyüz T 2007 Desalination 2141

33. Al-Anber M and Al-Anber Z A 2008 Desalination 22570

34. Bosco S M D, Jimenez R S and Carvalho W A $2005 \mathrm{~J}$. Colloid Inter. Sci. 281424

35. Zhang M L, Zhang H Y, Xu D, Han L, Niu D X, Tian B H, Zhang J, Zhang Y and Wu W S 2011 Desalination 271111 